https://journal.uwgm.ac.id/index.php/abdimasmahakam

E-ISSN: 2549-5755

Januari 2020, Vol. 4 No. 01

Received: September 2019

Accepted: Desember2019

Published: Januari 2020

Article DOI: http://dx.doi.org/ 10.24903/jam.v4i1.771

\title{
Pelatihan Cara Menggosok Gigi yang Benar pada Siswa TK 'Aisyiyah Purwodiningratan Yogyakarta
}

\author{
Menik Sri Daryanti \\ Universitas 'Aisyiyah Yogyakarta \\ meniksridaryanti@gmail.com
}

\begin{abstract}
Abstrak
Kesehatan gigi serta mulut merupakan salah satu hal yang penting karena dengan gigi dan mulut yang sehat maka setiap orang akan merasa nyaman untuk berbicara, makan, bersosialisasi dengan orang lain tanpa mengalami rasa sakit maupun malu. Masalah kesehatan gigi dan mulut yang paling umum dialami masyarakat adalah karies gigi. Menurut WHO (World Helath Organization) diseluruh dunia hampir 60-90\% anak sekolah memiliki karies gigi dan hampir $100 \%$ orang dewasa memiliki gigi berlubang. Kebiasaan menggosok gigi yang baik dapat mencegah karies gigi, karena menggosok gigi yang baik adalah salah satu tindakan yang paling efektif untuk mencegah karies gigi. Upaya menggosok gigi ini dapat menghilangkan plak atau deposit yang dapat menghilangkan bakteri lunak yang menempel pada gigi yang berakibat karies. Masih kurangnya informasi yang diperoleh para siswa tentang perawatan kesehatan gigi serta mulut merupakan hal yang masih terjadi, sehingga perlu diadakan pemberian informasi kepada siswa. Metode pelaksanaan dalam kegiatan ini dengan memberikan penyuluhan tentang kesehatan mulut dan pelatihan cara menggosok gigi yang benar. Dengan adanya penyuluhan dan pelatihan singkat cara menggosok gigi yang benar di sekolah ini diharapkan siswa dapat menerapkannya setiap hari di sekolah maupun di rumah, sehingga mengurangi kejadian karies gigi pada anak.
\end{abstract}

Kata Kunci: karies; gosok gigi; siswa.

\section{Pendahuluan}

Kesehatan gigi serta mulut merupakan salah satu hal yang penting karena dengan gigi dan mulut yang sehat maka setiap orang akan merasa nyaman untuk berbicara, makan, bersosialisasi dengan orang lain tanpa mengalami rasa sakit maupun malu. Masalah kesehatan gigi dan mulut yang paling umum dialami masyarakat adalah karies gigi. Menurut WHO (World Helath Organization) diseluruh dunia hampir 60-90\% anak sekolah memiliki karies gigi dan hampir $100 \%$ orang dewasa memiliki gigi berlubang.

Anak serta remaja kebanyakan mengalami masalah karies gigi, dengan kejadian karies paling tinggi pada usia 4-8 tahun pada gigi sulung dan usia 12-13 tahun pada gigi tetap, sebab pada usia itu email masih mengalami maturasi setelah erupsi, sehingga potensi terjadinya karies gigi lebih besar. Jika tidak mendapat perhatian karies gigi dapat menular menyeluruh dari gigi yang lain (Behrman,2002). 


\section{(A) ABDIMAS \\ https://journal.uwgm.ac.id/index.php/abdimasmahakam}

E-ISSN: 2549-5755

Januari 2020, Vol. 4 No. 01

Awal masuk sekolah merupakan tahap pertumbuhan dan perkembangan anak usia sekolah yang penting, banyak masalah yang terjadi pada anak sekolah seperti Perilaku Hidup Bersih dan Sehat (PHBS) mulai dari menggosok gigi dengan baik dan tepat, mencuci tangan memakai sabun, karies gigi, kecacingan, kelainan ketajaman pengelihatan dan masalah gizi, karena pelayanan kesehatan pada anak termasuk intervensi pada anak usia sekolah (Profil Kesehatan Indonesia, 2013).

Gigi anak sekolah yang terkena karies jika tidak dirawat dengan baik akan berdampak buruk terhadap gigi sehat yang lainnya, kemudian gigi karies sebelumnya akan lebih rapuh dan mudah patah. Komplikasi terjadi bila kuman masuk melalui lubang syaraf ke akar gigi, maka akan timbul peradangan menimbulkan nanah sebagai tanda inflamasi yang dikeluarkan tubuh melalui permukaan fistula di permukaan gusi. Infeksi kronis menahun pada satu atau lebih gigi primer yang bisa menyebabkan kerusakan gigi permanen yang sedang berkembang dibawahnya, dikhawatirkan mereka merasakan komplikasi dan minder terhadap gambaran dirinya (Sumawinata, 2008).

Tenaga kesehatan dapat memberikan penyuluhan kesehatan tentang kesehatan gigi di sekolah melalui kerja sama dengan pihak sekolah (Potter \& Perry,2005). Melalui pemeriksaan dengan cara melihat langsung yang merupakan bagian dari pengkajian, petugas kesehatan (Dokter/perawat/Bidan) dapat mengetahui status kesehatan gigi anak dan kebutuhan penyuluhan kesehatan gigi di keluarga dan sekolah (Wong,2008)

Kebiasaan menggosok gigi merupakan tindakan membersihkan gigi yang dilakukan seorang secara berkelanjutan. Waktu dan lamanya menyikat gigi bervariasi, tetapi kebanyakan peneliti mendapatkan bahwa lamanya menyikat gigi antara 2-3 menit sudah efektif membersihkan plak, durasi waktu optimal menyikat gigi bervariasi, bergantung pada efektivitas menghilangkan plak. Beberapa peneliti meyakini dengan durasi yang lebih lama maka lebih efektif untuk menghilangkan plak merekomendasikan 3 menit (Asdoorian, 2006).

Sunaryo (2002) menyatakan kebiasaan adalah bentuk perilaku yang tetap dari usaha adaptasi terhadap lingkungan yang mengandung unsur afektif perasaan. Kandani (2010) juga mengungkapkan bahwa kebiasaan adalah tindakan konsisten yang dilakukan secara berkelanjutan hingga membentuk suatu fase di level pikiran bawah sadar. Sementara itu, menurut Potter \& Perry (2005), mneggosok gigi adalah membersihkan gigi dari sisa makanan, bakteri dan plak. Ketika membersihkan gigi harus memperhatikan waktu yang tepat, penggunaan alat yang tepat dan cara yang tepat untuk membersihkan gigi.

\section{Metode}

Metode pelaksanaan kegiatan adalah dengan penyuluhan dan pelatihan singkat cara menggosok gigi yang benar pada siswa TK 'Aisyiyah Purwodiningratan Yogyakarta. Langkah-langkah yang dilakukan adalah bekerjasama dengan kepala sekolah dan guru TK 'Aisyiyah Purwodiningratan Yogyakarta guna berdiskusi kegiatan penyuluhan yang dilanjutkan dengan melakukan penyuluhan terkait cara menggosok gigi yang benar sebagai upaya pencegahan penyakit yang bisa terjadi pada gigi serta dalam rangka meningkatkan kesehatan gigi dan mulut. Selain itu dilakukan juga pelatihan cara menggosok gigi yang benar pada siswa TK 'Aisyiyah Purwodiningratan Yogyakarta agar bisa diterapkan setiap hari baik di sekolah maupun di rumah guna mengurangi kejadian karies gigi. 


\section{(A) ABDIMAS \\ https://journal.uwgm.ac.id/index.php/abdimasmahakam}

E-ISSN: 2549-5755

Januari 2020, Vol. 4 No. 01

\section{Hasil dan Pembahasan}

Strategi pelaksanaan kegiatan pengabdian masyarakat ini dilaksanakan dengan langkahlangkah yaitu persiapan, pelaksanaan dan evaluasi.

Pada tahap persiapan dilakukan persiapan untuk melaksanakan penyuluhan dan pelatihan cara menggosok gigi yang benar. Diawali dengan kegiatan survey tempat di TK 'Aisyiyah Purwodiningratan Yogyakarta. Selanjutnya diskusi dengan kepala dan guru TK 'Aisyiyah Purwodiningratan Yogyakarta untuk koordinasi penyuluhan dan pelatihan cara menggosok gigi yang benar. Selain itu dilakukan penyiapan alat dan bahan yang dibutuhkan untuk mendukung berjalannya pelatihan, seperti sikat gigi, pasta gigi, phantom gigi dan lain - lain serta persiapan doorprize yang akan diberikan apabila ada pertanyaan.

Untuk langkah selanjtunya yaitu tahap pelaksanaan yang dilakukan pada sebanyak 40 siswa di TK 'Aisyiyah Purwodiningratan Yogyakarta. Pada langkah ini dilakukan 2 kegiatan utama yaitu penyuluhan kesehatan dan pelatihan ara menggosok gigi yang benar.

Pada tahap penyuluhan kepada siswa TK 'Aisyiyah Purwodiningratan Yogyakarta mengenai cara menggosok gigi yang benar sebagai upaya pencegahan penyakit yang bisa terjadi pada gigi serta dalam rangka meningkatkan kesehatan gigi dan mulut. Tujuan dari penyuluhan kesehatan adalah diharapkan siswa TK 'Aisyiyah Purwodiningratan Yogyakarta mengerti dan mempraktekkan tentang cara menggosok gigi yang benar. Anak - anak tampak antusias mendengarkan materi yang disampaikan. Saat dilakukan diskusi tanya jawab, banyak ditemukan kebiasaan - kebiasaan anak yang kurang baik dilakukan yang erat kaitammya dengan kesehatan mulut, seperti makan makanan manis yang terlalu berlebihan setiap harinya dan lupa menggosok gigi setelah makan dan sebelum tidur.

Menurut Endelmen \& Mandle (2006) metode promosi kesehatan akan dapat membantu anak usia sekolah memahami keterkaitan antara perilaku kesehatan peningkatan kesehatan seperti metode mendemonstrasikan perilaku menggosok gigi.
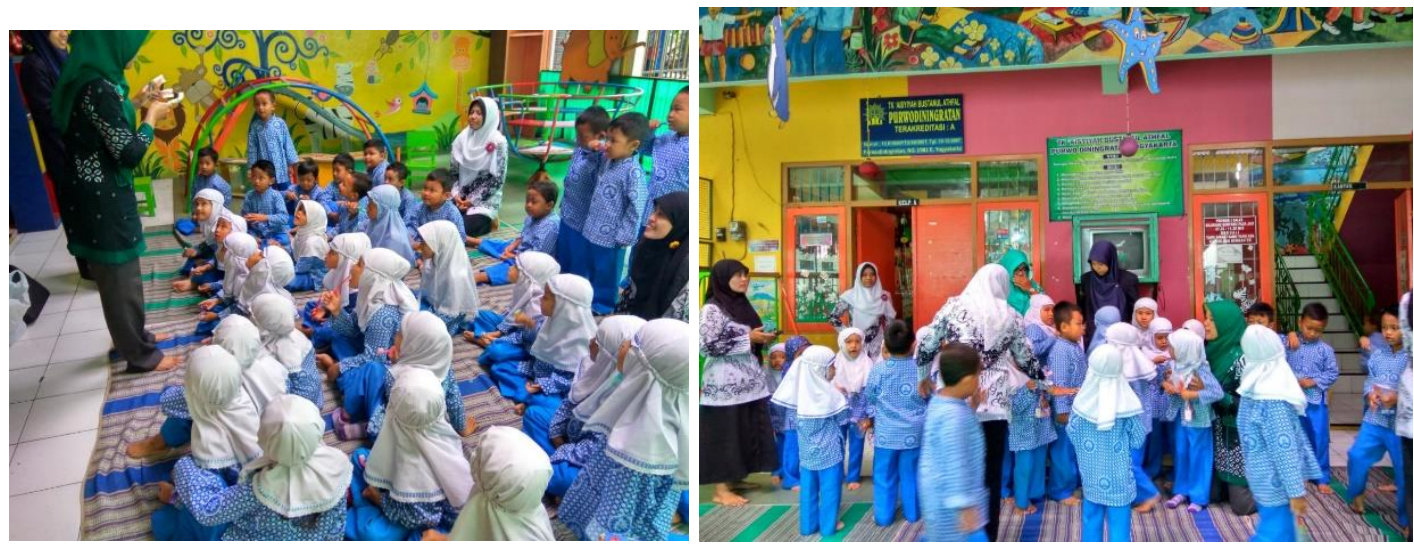

Gambar 1 dan 2 komunikasi dengan siswa

Pada tahap selanjutnya dilakukan pelatihan praktik cara menggosok gigi yang benar, kegiatan ini diadakan di halaman belakang TK 'Aisyiyah Purwodiningratan Yogyakarta yang dekat dengan sumber air. Pada tahap ini juga masih ditemukan tahapan cara memnggosok gigi yang kurang tepat.

Menurut Potter dan Perry (2005), anak masih memerlukan bantuan untuk menggosok gigi dengan tepat dan perlu diajari bagaimana cara melakukan perawatan gigi secara mandiri. 
Pada tahap akhir dilakukan evaluasi yaitu melakukan pemantauan/follow up terkait dengan keberlanjutan dalam praktik cara menggosok gigi yang benar pada siswa. Salah satunya adalah dengan mengajak anak - anak menggosok gigi setelah selesai kegiatan makan bersama di TK. Hssilnya anak - anak sudah bisa mempraktikkan cara menggosok gigi yang benar.

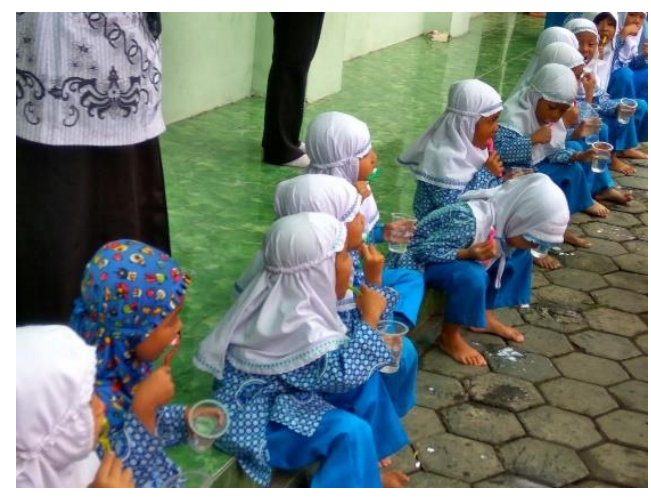

Gambar 3. Kegiatan menggosok gigi oleh siswa

\section{Simpulan dan rekomendasi}

Dari pengabdian masyarakat pelatihan cara menggosok gigi yang benar pada siswa TK 'Aisyiyah Purwodiningratan Yogyakarta dapat disimpulkan bahwa penyuluhan dan pelatihan cara memggosok gigi yang benar dapat memberikan pengetahuan tentang kesehatan gigi kepada anak - anak TK serta dapat menumbuhkan kebiasaan untuk selalu menjaga kesehatan gigi dan mulut.

Bagi guru dan orang tua hendaknya mengingatkan anak untuk selalu menjaga kesehatan gigi serta mulut agar terhindar dari masalah kesehatan gigi serta mulut, contohnya yang paling sering ditemui pada usia anak - anak adalah karies. 
https://journal.uwgm.ac.id/index.php/abdimasmahakam

E-ISSN: 2549-5755

Januari 2020, Vol. 4 No. 01

\section{Daftar Pustaka}

Asdoorian, J., 2006. Toothbrushing. Can J. Dent Hygiene, 40(5):1-14

Behrman, R.E dkk. 2002. Ilmu Kesehatan Anak Nelson (Vol .2) ( $5^{\text {th }}$ Ed) (A. Samik Wahab, Editor). Jakarta: EGC.

Endelman, C.L, \& Mandle, C.L. 2006. Health Promotion:Thoroughout the Life Span. St Louis : Mosby.

Kandani,H. 2010. The Achiever:Semua Pencapaian Sukses anda Berawal dari sini . Jakarta: PT Elex Media Komputindo.

Potter, P.A, \& Perry,A.G (2005). Buku Ajar Fundamental Keperawatan: Konsep, Proses dan Praktik. Jakarta: EGC.

Sumawinata, N. 2008. Dasar-dasar Karies Penyakit dan Penanggulangannya. EGC: Jakarta Sunaryo. 2004. Psikologi untuk Keperawatan. Jakarta: EGC.

Wong dkk . 2008. Buku Ajar Keperawatan Pediatrik. Jakarta: EGC. 